\begin{tabular}{c} 
Volume and Issues Obtainable at Center for Sustainability Research and Consultancy \\
Journal of Business and Social Review in Emerging Economies \\
ISSN: 2519-089X (E): 2519-0326 \\
Volume 5: No. 2, December 2019 \\
CSRᄃ \\
Joournal homepage: www.publishing.globalcsrc.org/jbsee \\
\hline
\end{tabular}

\title{
Determinants of Service Quality and Customer Satisfaction of Retail Clothing
} Company

\author{
${ }^{1,2}$ Tak Jie Chan $\&^{3}$ Mei Ling Goh \\ ${ }^{1}$ Faculty of Communication and Creative Design, SEGi University, 47810, Petaling Jaya, Selangor, Malaysia. \\ chantakjie@segi.edu.my \\ ${ }^{2}$ Putra Business School, 43400 UPM Serdang, Selangor, Malaysia. takjie.phd mkt18@grad.putrabs.edu.my \\ ${ }^{3}$ Faculty of Business, Multimedia University, 75450, Bukit Beruang, Melaka, Malaysia. mlgoh@mmu.edu.my
}

\begin{tabular}{l}
\hline \multicolumn{1}{c}{ ARTICLE DETAILS } \\
\hline History \\
Revised format: November 2019 \\
Available Online: December 2019
\end{tabular}

\section{Keywords}

Service Quality, Customer

Satisfaction, SERVQUAL, Clothing Industry

JEL Classification:

L15,L19, P29

\begin{abstract}
The study aims to investigate the relationship between service quality and customer satisfaction in a retail clothing company. The study utilized the SERVQUAL model to guide the study. Purposive sampling was applied in the study where quantitative (survey) method was employed with generating 140 valid responses. The data were then analyzed using Partial Least Squares Structural Equation Modelling through Smart-PLS 3.0. The results revealed that three (3) dimension of SERVQUAL (tangibles, empathy, and responsiveness) has a positive and significant relationship with customers. However, reliability and assurance yielded negative with customer satisfaction. In addition, out of the five determinants of SERVQUAL, assurance was found not significant to customer satisfaction. Conclusion, implications, and suggestions for future study are also discussed.
\end{abstract}

(C) 2019 The authors, under a Creative Commons AttributionNonCommercial 4.0

Corresponding author's email address: chantakjie@ @egi.edu.my

Recommended citation: Chan, T. J. and Goh, M. L., (2019). A Determinants of Service Quality and Customer Satisfaction of Retail Clothing Company. Journal of Business and Social Review in Emerging Economies, 5 (2), 295-304

DOI: $10.26710 /$ jbsee.v5i2.840

\section{Introduction}

Service quality has become a significant aspect of service marketing to gauge the survival of the companies, especially in the turbulent emerging business environment (Omar, Ariffin, \& Ahmad, 2016). Therefore, understanding the perception of customers on how they perceived the services of the companies has become a pivotal agenda of the service firms. Numerous past studies have highlighted the outcomes of having a good service quality such as improving market share and sales (Becerril-Arreola, Zhou, Srinivasan, \& Seldin, 2017), increase customer satisfaction and loyalty (Alauddin, Ahsan, Mowla, Islam \& Hosain, 2019; Leinkumar, 2017).

In Malaysia, retail service sector set for stronger sales projected to grow by 4.7 or RM104.4 billion in the year 2018 as compared to the growth seen in the year 2017 (Kana, 2018). In addition, according to the Statista (2018), market demand for clothing or apparel industry in Malaysia from 2011 to 2018 showed a positive growth, and expected to reach 7 billion US dollars in the year 2018. In addition, Textiles Intelligence (2018), reported that the Malaysian clothing industry employs over 90,000 people and the Malaysian government aims to export target of US $\$ 6$ bn for 
the year 2020, which indicated that the clothing industry as an important sector which contributed to the national Gross Domestic Products (GDP).

However, there are many challenges faced by the clothing industry, for example, issues with the labour trafficking and foreign workers as the clothing industry required many workforces to manufacture the products (Suhrawardi, 2019), factory closures and relocations due to many competitors and unstable economy (Crinis, 2012). Hence, without the skills and knowledgeable workforce, it will affect the services provided by the company and results in customer dissatisfaction as Hui and Yee (2015) argued that frontline employees who have direct interactions with the consumers has a significant effect on customer satisfaction.

Although numerous past research have been examined on the service quality and various customer outcomes which focused on various industries, such as hotel and restaurant (Omar, et al., 2016; Priyo, Mohamad, Adentunji, 2019; Shah, Jan, \& Baloch, 2018), airlines (Khuong \& Uyen, 2014), telecommunication (Danish, Humayon, Iqbal, Raza, \& Shahid, 2018; Tariq \& Nik Mat 2018); education (Kundi, Khan, Qureshi, Khan, \& Akhtar, 2014; Singh \& Kumar, 2016), banking (Ali \& Raza, 2017; Rouf, Kamal, \& Iqbal, 2018; Whingan \& Ogundare, 2018) and some textile industry have also been found (Luximon \& Chan, 2017; Singh \& Aggarwal, 2017). However, those studies required further investigation in Malaysian setting as different countries have different social economic status and the segmentation of customers were also vary.

In addition, majority studies who did on the retail sectors focusing on the retail service quality scale (RSQS) (Asare, Xu Ming, 2016; Jain \& Aggarwal, 2018). However, there are also some arguments that SERVQUAL also applicable to test on the retail sectors (Bat-Ochir, Bold, Sodnom-Ochir, Sodnom-Ochir, \& Munkhbat, 2018; Hisham, Sanyal, \& Ahmad, 2016; Selvabaskar \& Shanmuga Priya, 2015). Hence, due to inconsistency argued in the literature, it has urged the researchers to retest again the study by using the SERVQUAL model. Based on the notion above, therefore, the current research intends to investigate the service quality and customer satisfaction of a retail clothing brand in Malaysian setting.

\section{Literature Review}

\subsection{Related Past Studies of Service Quality and Customer Satisfaction}

Mistri and Bhatt (2013) tried to investigate the attributes that influence perception of consumers towards service quality of hypermarkets in Ahmedabad City, Gujarat. The study utilized RSQS (Dabholkar, Thorpe, \& Rentz, 1996) which measure on the physical aspect, reliability, personal interaction, problem solving, and policy. The study comprised of 240 active retail shoppers by using convenience sampling and analyzed using factor analysis. The findings revealed that the results do not support the five dimensions that proposed by the Dabholkar et al., (1996), as the analysis gave eight dimensions. Based on the discussion, it has urged the management of the retail shoppers still can apply the five (5) dimensions as the foundation in improving the service quality of retail stores, however, when the countries developed, the behavior of the consumers will also change accordingly, whereby consumer may consider the intangible aspects more prominently in service quality.

In addition, Selvabaskar and Shanmuga Priya (2015) carried out a study to investigate the customer satisfaction of a fashion apparel retail in Chennai, India by using the SERVQUAL model. The results of the study shown that most of the customers are satisfied with most of the SERVQUAL dimensions. In addition, the analysis shows that there is a weak and positive relationship between income and quantity of purchase.

Luximon and Chan (2017) aimed to investigate the expectation of service quality and cultural diversity in Hong Kong fast fashion industry. The service quality expectation comprised of physical aspect, reliability, personal interaction, problem solving, and policy. The findings confirmed the importance of cultural factors in shaping service quality of consumers. Based on the discussion, every customer will have different expectations and preferences on the services provide by the retailers, hence, the fashion retailers should understand the customers' expectation in order to stay competitive advantage among its rivals.

Shahneaz and Salma (2013) aim to examine the customer satisfaction of service quality at Mega Shops of Dhaka city. The findings of the regression analysis shown tangible, customer knowledge, and competence has a significant effect on overall customer satisfaction, however, responsiveness does not showed significant relationship with the overall customer satisfaction of retail stores. Based on the discussion, it has called upon the management of the retail store to improve on the responsiveness and main the other attributes of service quality. This is because service quality serves as a marketing tool in differentiating the company and its rivals. 
Hisham et al., (2016) aimed to study the impact of service quality on the satisfaction of consumers in retail stores in Indian using SERVQUAL and GAP models. Random sampling has been utilized to collect the data, which comprised of 300 respondents from 3 cities of India (Kolkata, Varanasi, and Ranchi). The results of the study shown that tangibility, reliability, responsiveness, assurance, and empathy dimensions were integrated into all the three retail companies in selected cities. In addition, tangibility has a bigger gap as compared to other attributes. Based on the study, it had urged the management of the retail store to focus on the visual characteristics which are appealing to the customer (tangibility). Besides, retail outlet's employees at reception desk should also be neat to appear pleasant to the customers as employees are the identity and brand of the corporations.

Kundi et al., (2014) tried to examine the effects of service quality and customer satisfaction in one of the Higher Education Institutions in Pakistan. The study utilized SERVQUAL model and the findings revealed that there are positive and significant relationships between all the attributes (tangibility, reliability, assurance, responsiveness, assurance, empathy) with customer satisfaction. In addition, tangibility and assurance considered as the two determinants to improve the service quality of higher education system. Based on the above discussion, service quality has become a significant marketing tool in attracting and retain customers. This can be further explained that university nowadays had transformed become like a business entity, hence, staff and student satisfaction and their expectation become important as they are the stakeholders which bring the survival of the institution.

Rajeswari, Srinivasulu, and Thiyagarajan (2017) intent to analyze the interrelationship among service quality, customer satisfaction, and customer loyalty in the Wireline Telecom companies. The study employed multistage sampling to gather responses from 381 broadband customers. Structured questionnaires were distributed and the instrument was based on SERVQUAL and E-S-Qual model. The findings revealed that customer satisfaction has a mediating effect between service quality and customer loyalty.

In addition, Huang, Lee, and Chen (2017) aims to investigate the service quality on customer satisfaction and loyalty in business-to-business (B2B) technology service industry. The study utilizes PZB model to guide the study. The findings revealed that service quality (tangibility, reliability, responsiveness, assurance, and empathy) positively influences customer satisfaction. Moreover, customer satisfaction has a positive effect on customer loyalty, and brand awareness plays the role as a moderator which positively influence the relationship between those variables.

Based on the above notion, competition among Telco companies is very challenging. Hence, every company should satisfy their customers by providing high and good quality services. The company should make their internal customers, which are the employees satisfied with their services before project to the external customers, as the internal customers can be an ambassador for the company to market the effective service quality to the clients and contribute to the customers' satisfaction and lead to the loyalty in the long run.

In addition, Jaskulska (2013) intends to test the prediction of customer satisfaction through the dimensions of service and product quality in the ZARA clothing retail industry in Ireland. The study applied SERVQUAL for quality service as a basis for constructing the instrument. Based on the findings, the customers seem satisfied with ZARA personnel and they agree that reliability, responsiveness, and credibility are the factors that meet their expectations. In addition, the results explained that understanding and serviceability are the predictors which influence customer satisfaction.

Tessera, Hussain, and Ahmad (2016) aims to investigate the service quality and customer satisfaction in the Ethiopia hotel industry by utilizing the SERVQUAL model. The findings revealed that three (3) dimension of SERVQUAL namely, tangibles, responsiveness, and empathy had high significant effects on customer satisfaction. This has aligned with several literature who gained the similar results which indicate the significant relationship between service quality and customer satisfaction (Alauddin et al., 2019; Bat-Ochir et al., 2018).

Ali and Raza (2017) wish to investigate the service quality and customer satisfaction of Pakistan Islamic banks. The study applied SERVQUAL model which comprised of compliance, assurance, reliability tangibles, empathy, and responsiveness. The result showed that the SERVQUAL model has a positive and significant influence on customer satisfaction. In addition, the compliance proved to be the highest contributing factors in the model. 
In the same vein, Whingan and Ogundare (2018) aims to examine the perceptions of customers on bank service quality and customer satisfaction. The results showed that three facets of service quality, namely, reliability, empathy, and assurance have a positive significant relationship with customer satisfaction. However, tangibility was found not significant to customer satisfaction.

In the hotel industry, Ahmad, Ahmad, and Papastathopoulous (2019) intend to investigate the service quality by applying the SERVQUAL model of customer satisfaction on 232 hotel guests in United Arab Emirates (UAE). The findings confirmed the three (3) dimensions of SERVQUAL: tangible, responsiveness, and assurance have a significant positive impact on customer satisfaction. However, reliability and empathy do not have a significant impact on visitors' satisfaction.

Omar et al., (2016) intend to examine between service quality and customer satisfaction moderated by customers' gender in Arabic restaurants. The findings showed that all the five service quality attributes have a positive relationship with customer satisfaction. However, the results of hierarchical regressions indicated that tangibles, assurance, and empathy have a significant positive relationship with customer satisfaction, but reliability and responsiveness were found insignificant. In addition, gender plays a significant role in moderate the service quality and customer satisfaction.

Based on the discussion above, therefore, the study hypothesizes that:

H1: Tangibles will have a positive relationship with customer satisfaction.

H2: Reliability will have a positive relationship with customer satisfaction.

H3: Assurance will have a positive relationship with customer satisfaction.

H4: Empathy will have a positive relationship with customer satisfaction.

H5: Responsiveness will have a positive relationship with customer satisfaction.

\section{Methodology}

\subsection{Research Design}

This study utilized a quantitative (survey) design, whereby a structured self-administered, anonymous questionnaire had been distributed to the customers who have experiences buying the particular clothing brand. Survey design allows the researcher to effectively determine the opinions of respondents about a particular subject from a specific group of people (Babbie, 2016). Hence, the deductive approach by using the survey is deemed to be the suitable method to apply in this study.

\subsection{Population and Sampling}

A total of 140 completed questionnaires was collected. According to Sekaran and Bougie (2016), a sample size range from 30 to 500 would be sufficient and acceptable for the social science studies. Convenience and purposive sampling was used to collect the data from the customers, where the customers must have experiences purchasing the clothing brand as part of the criterion before the customers answer the questionnaire.

\subsection{The Measurement}

The instrument comprised of three (3) sections. Section A is a demographic profile of the respondents. Section B consists of the items pertaining to the facets of service quality, which comprised of tangibles, reliability, assurance, empathy, and responsiveness. Section $C$ is the items pertaining to customer satisfaction. Demographic questions in Section A were designed to gather information about the respondents' gender, age, race, and income. Section B is regards the specific dimensions of service quality that comprised of five (5) facets that adopted from Parasuraman, Zeithmal, and Berry (1988). The survey items for Section B was measured based on a five-point Likert-type scale where 1 represents "Strongly Disagree"; 2 represents "Disagree"; 3 indicates "Slightly Agree"; 4 represents "Agree"; and 5 indicates as "Strongly Agree". Whilst for Section C, customer satisfaction the items were adapted from the Oliver (1997) and Lee-Kelley, Davies, \& Kangis (2002) that measured on the five-point Likert-type scale where 1 indicates "Very Dissatisfied"; 2 represents "Dissatisfied; 3 indicates "Somewhat Satisfied"; 4 represents "Satisfied"; and 5 indicates "Very Satisfied". 


\subsection{Statistical Analysis and Significance}

All the hypotheses developed were tested using Structural Equation Modelling (SEM). Two-stage analytical procedures were performed using Smart-PLS. SEM is deemed a suitable statistical tool for this study as PLS-SEM can handle complex models where there are many numbers of latent variables and constructs (Henseler, Ringle, \& Sinkovics, 2009). In addition, PLS-SEM can also handle the data from non-probability sampling, with a small sample size and from non-normal distribution data (Awang, Afthanorhan, Asri, 2015; Hair, Risher, Sarstedt, \& Ringle, 2019).

\section{Results}

Out of 140 respondents recruited in the study, $66.4 \%$ were female and $33.6 \%$ were male. Majority of respondents were Malay (52.1\%), 15.7\% were Chinese and 9.3\% were Indian. Almost $86 \%$ of the respondents were from the income group which less than RM1500 per month, followed by income group between RM1500 to RM3000 $(11.4 \%)$.

\subsection{Measurement Model}

For the measurement model, convergent validity and discriminant validity were assessed. The convergent validity of the measurement model was ascertained through factor loadings, average variance extracted (AVE) and composite reliability (CR) (Hair, Hult, Tomas, Ringle, \& Sarstedt 2017).

As presented in Table 1, the factor loadings were all greater than 0.5 which is suggested by Hair, Ringle \& Sarsterd (2011). Three items, EMP2, REL2, and TAN3 with factor loading less than 0.5 were deleted. In addition, the AVE and CR obtained were also higher than 0.5 and 0.7 respectively (Hair et al., 2017).

Two criteria, Fornell-Larcker (1981) and Heterotrait-monotrait (HTMT) (Henseler, Ringle \& Sarstedt, 2015) was used to assess the discriminant validity. Table 2 shows that all the square roots of AVE (diagonal values) are more than the correlation coefficients between the constructs (off diagonal values), indicating discriminant validity is met (Fornell-Larcker, 1981). Discriminant validity is established if all the HTMT values obtained are less than the required threshold of HTMT.90 as per suggested by Gold, Malhotra \& Segars (2001). As shown in Table 3, all the HTMT values passed HTMT.90 indicating that discriminant validity is ascertained. Collinearity issue was assessed using variance inflation factor (VIF) with a cut-off value of 5 as suggested by Hair et al., (2017). The VIF values as presented in Table 4 were all less than 5 indicating no collinearity issues.

Table 1: Convergent Validity

\begin{tabular}{|l|l|l|l|l|l|}
\hline Construct & Items & Loadings & $\begin{array}{l}\text { Cronbach's } \\
\text { alpha }\end{array}$ & CR & AVE \\
\hline Assurance & ASS1 & 0.784 & 0.781 & 0.858 & 0.604 \\
\hline & ASS2 & 0.649 & & & \\
\hline & ASS3 & 0.864 & & & \\
\hline & ASS4 & 0.795 & & & \\
\hline Empathy & EMP1 & 0.703 & 0.757 & 0.833 & 0.557 \\
\hline & EMP3 & 0.644 & & & \\
\hline & EMP4 & 0.828 & & & \\
\hline & EMP5 & 0.797 & & & 0.653 \\
\hline Reliability & REL1 & 0.844 & 0.831 & 0.882 & \\
\hline & REL3 & 0.747 & & & \\
\hline & REL4 & 0.781 & & & \\
\hline & REL5 & 0.855 & & & 0.718 \\
\hline Responsiveness & RES1 & 0.839 & 0.869 & 0.910 & \\
\hline & RES2 & 0.797 & & & \\
\hline & RES3 & 0.887 & & & \\
\hline & RES4 & 0.863 & & & \\
\hline Tangibles & TAN1 & 0.795 & 0.635 & 0.772 & \\
\hline
\end{tabular}




\begin{tabular}{|l|l|l|l|l|l|}
\hline & TAN2 & 0.511 & & & \\
\hline & TAN4 & 0.854 & & & \\
\hline Satisfaction & CS1 & 0.817 & 0.742 & 0.839 & 0.569 \\
\hline & CS2 & 0.831 & & & \\
\hline & CS3 & 0.653 & & & \\
\hline & CS4 & 0.700 & & & \\
\hline
\end{tabular}

Table 2: Discriminant Validity Using Fornell-Larcker Criterion

\begin{tabular}{|l|l|l|l|l|l|l|}
\hline & Assurance & CS & Empathy & Reliability & Responsiveness & Tangibles \\
\hline Assurance & 0.777 & & & & & \\
\hline Satisfaction & 0.346 & 0.754 & & & & \\
\hline Empathy & 0.599 & 0.515 & 0.746 & & & \\
\hline Reliability & 0.692 & 0.305 & 0.579 & 0.808 & & \\
\hline Responsiveness & 0.552 & 0.520 & 0.709 & 0.555 & 0.847 & \\
\hline Tangibles & 0.445 & 0.505 & 0.392 & 0.498 & 0.359 & 0.735 \\
\hline
\end{tabular}

Table 3: Discriminant Validity Using HTMT Ratio

\begin{tabular}{|l|l|l|l|l|l|l|}
\hline & Assurance & CS & Empathy & Reliability & Responsiveness & Tangibles \\
\hline Assurance & & & & & & \\
\hline CS & 0.446 & & & & & \\
\hline Empathy & 0.839 & 0.622 & & & & \\
\hline Reliability & 0.887 & 0.351 & 0.721 & & & \\
\hline Responsiveness & 0.688 & 0.632 & 0.828 & 0.631 & & \\
\hline Tangibles & 0.610 & 0.595 & 0.454 & 0.628 & 0.394 & \\
\hline
\end{tabular}

\subsection{Structural Model}

The structural model was tested using bootstrapping procedures with a resample of 10,000 (Andrews \& Buchinsky, 2002; Streukens, \& Leroi-Werelds, 2016) to assess all the relationships between the constructs, its corresponding beta and t-values. The results are shown in Table 4.

Tangibles $(\beta=0.401, \mathrm{t}=4.930, \mathrm{f} 2=0.206)$, empathy $(\beta=0.270, \mathrm{t}=2.587, \mathrm{f} 2=0.054)$ and responsiveness $(\beta=$ $0.313, \mathrm{t}=2.924, \mathrm{f} 2=0.079)$ were found to have a positive relationship with customer satisfaction. However, reliability $(\beta=-0.211, \mathrm{t}=2.048, \mathrm{f} 2=0.034)$ and assurance $(\beta=-0.021, \mathrm{t}=0.162, \mathrm{f} 2=0.000)$ were found to have a negative relationship with customer satisfaction. The assurance, however, showed no significant relationship with customer satisfaction. This gives support for $\mathrm{H} 1, \mathrm{H} 2, \mathrm{H} 4$, and $\mathrm{H} 5$ except for $\mathrm{H} 2 . \mathrm{R}^{2}$ of 0.433 suggesting there is $43.3 \%$ of the variation in customer satisfaction was explained by the service quality. 


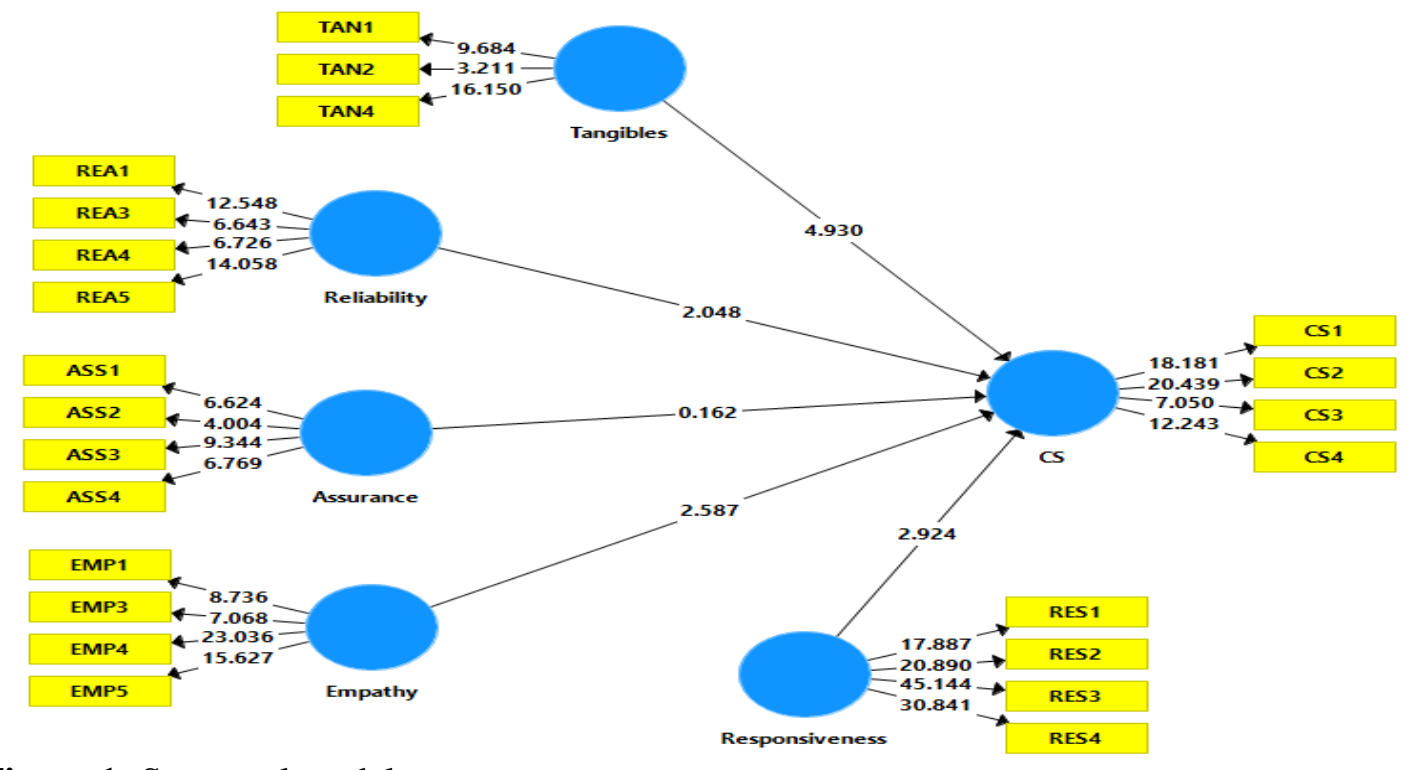

Figure 1: Structural model

Table 4: Direct Effects

\begin{tabular}{|l|l|l|l|l|l|l|l|l|l|}
\hline Hypothesis & Relationship & $\begin{array}{l}\text { Std. } \\
\text { Beta }\end{array}$ & $\begin{array}{l}\text { Std. } \\
\text { Error }\end{array}$ & t-value & Decision & R2 & Q2 & f2 & VIF \\
\hline H1 & Tangibles -> Satisfaction & 0.401 & 0.081 & $4.930^{* *}$ & Supported & 0.433 & 0.208 & 0.206 & 1.379 \\
\hline H2 & Reliability -> Satisfaction & -0.211 & 0.103 & $2.048^{*}$ & Supported & & & 0.034 & 2.289 \\
\hline H3 & Assurance -> Satisfaction & -0.021 & 0.128 & 0.162 & $\begin{array}{l}\text { Not } \\
\text { Supported }\end{array}$ & & & 0.000 & 2.224 \\
\hline H4 & Empathy -> Satisfaction & 0.270 & 0.104 & $2.587 * *$ & Supported & & & 0.054 & 2.367 \\
\hline H5 & $\begin{array}{l}\text { Responsiveness } \\
\text { Satisfaction }\end{array}$ & 0.313 & 0.107 & $2.924^{* *}$ & Supported & & & 0.079 & 2.178 \\
\hline$* * p<0.01, * p<0.05$ & & & & & & & & \\
\hline
\end{tabular}

\section{Discussion}

The findings have supported the study of Hisham et al., (2016) which showed that tangibility, reliability, responsiveness, assurance and empathy dimensions were integrated into all three retail companies in the selected cities of India. However, the current results partially aligned with the study of Kundi et al., (2014) who found positive and significant relationships between all the service quality dimension and customer satisfaction, but the current study showed that the reliability and assurance having a negative relationship with customer satisfaction. The plausible reasons could be that the particular clothing brand still does not gain the full trust of their customers, wherein customers may have doubts on the reliability of the information and promises given by the clothing company which caused the two dimension having the negative results.

The current study was contrasted with Whingan and Ogundare's (2018) findings who revealed that three (3) facets of service quality, namely, reliability, empathy, and assurance have a positive significant relationship with customer satisfaction. Furthermore, Ahmad et al., (2019) found that tangible, responsiveness and assurance have a significant positive impact on customer satisfaction. However, reliability and empathy have no significant impact on visitors' satisfaction.

In addition, Omar et al., (2016) showed that tangibles, assurance and empathy have a significant positive relationship with customer satisfaction, but reliability and responsiveness were found insignificant in the restaurant. Based on the above discussion, it has shown that different customers perceived the service quality dimension differently across different industries and sectors.

The positive results of this study support the notion that customers of the particular clothing company are likely to satisfy with the services of the firms which have high quality product with reasonable price, nice ambience, and good environment, as it explained the tangibility of the services towards the satisfaction of the customer. In 
addition, the responsiveness of the current study showed that it is a highest predictor $(31.3 \%)$. This have urged the management of the retail clothing to train their employees to know their product and services well, as the frontline employees are the brand of the company. Hence, it showed that the particular clothing brand employees are knowledgeable about their products and services, hence, they are responsive to the customers' inquiry.

However, reliability and assurance found negative results which urged the management of the clothing company to have more reliable information about the products (material used, price, shipping fees) to be displayed on the social media like internet, Facebook, and Instagram, so that customers can have the direct access about the information online and the assurance can be gained and met.

In summary, the clothing company should focus on the identified facets of service quality as part of their marketing strategy to achieve profitability. This recommendation is made because service quality is vital in gaining competitive advantages among other rivals, which will have a significant impact in attracting prospective customers as well as retaining the current ones.

\section{Conclusion}

This research intends to investigate the relationships between the five (5) dimensions of the service quality and customer satisfaction of a retail clothing brand from the Malaysia consumers' perspective which are tangibility, reliability, assurance, empathy, and responsiveness. The PLS SEM results revealed that three (3) dimensions of SERVQUAL contributed $43.3 \%$ towards the customer satisfaction in the Malaysian setting.

\subsection{Implications}

In terms of academic implications, this research contributed to the existing marketing literature empirically by proving the SERVQUAL model which developed by Parasuraman et al., (1988) is still applicable in the Malaysia retail setting. The study has widened the knowledge base regarding on the practicality and suitability of the SERVQUAL model in the retail clothing industry which operate under a multicultural market.

Since the determinants, namely tangibles, responsiveness, empathy, and reliability are found contribute significantly to customer satisfaction, the retail clothing company should pay more attention to these determinants. For instance, the management of the clothing company should advocate reliable and truthful information regards the product $\&$ services and the company philosophy. This will help gain stronger confidence and higher admiration among customers. Ultimately, the findings will inspire other clothing industry to re-evaluate the effectiveness of their business and marketing strategies to convey to the stakeholders, especially the customer in achieving stronger sustainability and survival.

\subsection{Limitations \& Suggestions for Future Study}

The study possesses several limitations. Firstly, this study has used non-probability sampling technique (purposive sampling) which limit the generalizability of the results. Future studies are recommended to employ probability sampling techniques under similar context, so that there will be more generalizability of the data.

Secondly, this study only focused on the current customers as one of the stakeholder group. Future research should therefore include different combinations of stakeholder groups (such as employees, potential customer). It is also interesting to make comparisons between different brand of clothing companies or other service industries to add more perspectives into the marketing research.

Thirdly, there are other variables, which were currently not being investigated in this study, which can contribute $56.7 \%$ of the variation in explaining the customer satisfaction. Hence, future studies can include some other outcome variables as suggested by literature such as trust, customer loyalty, word-of-mouth, and demographic variables to test the moderating and mediating effects of the model to enhance the field of service marketing.

\section{References}

Ahmad, S. Z., Ahmad, N., \& Papastathopoulos, A. (2019). Measuring service quality and customer satisfaction of the small- and medium-sized hotels (SMSHs) industry: Lessons from United Arab Emirates (UAE). Tourism Review, 74(3), 349-370. doi 10.1108/TR-10-2017-0160

Alauddin, M., Ahsan, S. M. H., Mowla, M. M., Islam, M. M., \& Hossain, M. M. (2019). Investigating the relationship between service quality, customer satisfaction and customer loyalty in hotel industry: 
Bangladesh perspective. Global Journal of Management and Business Research: A Administration and Management, 19(1), 29-35.

Ali, M., \& Raza, S. A. (2017). Service quality perception and customer satisfaction in Islamic banks of Pakistan: The modified SERVQUAL model. Total Quality Management, 28(5), $559 \quad-577$. doi.org/10.1080/14783363.2015.1100517

Andrews, D. W., \& Buchinsky, M. (2002). On the number of bootstrap repetitions for BCa confidence intervals. Econometric Theory, 18, 962-984.

Asare, D., \& Xu Ming. (2016). Significant services that have high impact on customer satisfaction: A study of selected foreign fashion stores in Shanghai. International Journal of Education and Social Science, 3(2), 6674.

Awang, Z., Afthanorhan, A., Asri, M. A. M. (2015). Parametric and non-parametric approach in structural equation modeling (SEM): The application of bootstrapping. Modern Applied Science, 9(9), 58-67.

Babbie, E. R. (2016). The practice of social research (14th ed.). Cengage Learning

Bat-Ochir, T., Bold, B., Sodnom-Ochir, M., Sodnom-Ochir, J., \& Munkhbat, U. (2018). Customer satisfaction survey of fast fashion brand loyalty in Mongolia. International Journal of Management and Applied Science, 4(2), 29-34.

Becerril-Arreola, R., Zhou, C., Srinivasan, R., \& Seldin, D. (2017). Service satisfaction-market share relationships in partnered hybrid offerings. Journal of Marketing, 81(5), 86-103.

Crinis, V. (2012). Global commodity chains in crisis: The garment industry in Malaysia. Institutions and Economies, 4(3), 61-82.

Dabholkar, P. A., Thorpe, D. I., \& Rentz, J. O. (1996). A measure of service quality for retail stores: Scale development and validation. Journal of the Academy of Marketing Science, 24, 3-16. doi.org/10.1007/BF02893933

Danish, R. Q., Humayon, A. A., Iqbal, H. J., Raza, S., \& Shahid, J. (2018). The impact of service quality and service value on customer satisfaction through customer bonding: Evidence from telecommunication sector. European Online Journal of Natural and Social Sciences, 7(1S), 40-47.

Fornell, C., \& Larcker, D. F. (1981). Evaluating structural equation models with unobservable variables and measurement error. Journal of Marketing Research, 18(1), 39-50.

Gold, A. H., Malhotra, A., \& Segars, A. H. (2001). Knowledge management: An organizational capabilities perspective. Journal of Management, 18(1), 185-214.

Hair, J. F., Hult, G., Tomas, M., Ringle, C. M., \& Sarstedt, M. (2017). A primer on Partial Least Squares Structural Equation Modeling (PLS-SEM): SAGE Publications, Incorporated.

Hair, J. F., Ringle, C. M., \& Sarstedt, M. (2011). PLS-SEM: Indeed a silver bullet. Journal of Marketing Theory and Practice, 19(2), 139-151.

Hair, J., Risher, J., Sarstedt, M., \& Ringle, C. (2019). When to use and how to report the results of PLSSEM. European Business Review, 31(1), 2-24.

Henseler, J., Ringle, C. M., \& Sinkovics, R. R. (2009). The use of partial least squares path modeling in international marketing. Advances in International Marketing, 20, 277-319.

Henseler, J., Ringle, C. M., \& Sarstedt, M. (2015). A new criterion for assessing discriminant validity in variancebased structural equation modelling. Journal of the Academy of Marketing Science, 43(1), 115-135.

Hisam, M. W., Sanyal, S., \& Ahmad, M. (2016). The impact of service quality on customer satisfaction on selected retail stores in India. International Review of Management and Marketing, 6(4), 851-856.

Huang, P. L., Lee, B. C. Y., \& Chen, C. C. (2017). The influence of service quality on customer satisfaction and loyalty in B2B technology service industry. Total Quality Management \& Business Excellence, 1-17. doi: 10.1080/14783363.2017.1372184

Hui, S. L., \& Yee, R. W. Y. (2015). Relationship among interpersonal relationship, customer satisfaction and brand loyalty in fashion retailing industry. Research Journal of Textile and Apparel, 19(1), 65-72.

Jain, P., \& Aggarwal, V. S. (2018). Developing a service quality scale in context of organized grocery retail of India. Management Decision, 56(9), 1969-1990. doi 10.1108/MD-08-2017-0790

Jaskulska, J. (2013). Quality of service and product as the main factors influencing customers' satisfaction in the clothing retailing industry in Ireland- case study of ZARA Plc. Unpublished MBA project, Dublin Business School. Retrieved from https://esource.dbs.ie/bitstream/handle/10788/1713/mba_jaskulska_j_2013.pdf?sequence=1\&isAllowed=y

Kana, G. (March 15, 2018). Retail sector set for stronger sales growth this year. Retrieved from https://www.thestar.com.my/business/business-news/2018/03/15/retail-sector-set-for-stronger-salesgrowth-this-year/ on June 16, 2018. 
Khuong, M. N., \& Ugyen, L. T. M. (2014). The factors affecting Vietnam airlines service quality and passenger satisfaction: A mediation analysis of service quality. International Journal of Innovation, Management and Technology, 5(5), 327-333.

Kundi, G. M., Khan, M. S., Qureshi, Q. A., Khan, Y., \& Akhtar, R. (2014). Impact of service quality on customer satisfaction in higher education institutions. Industrial Engineering Letters, 4(3), 23-28.

Lee-Kelley, L., Davies, S., \& Kangis, P. (2002). Service quality for customer retention in the UK steel industry: Old dogs and new tricks? European Business Review, 14(4), 276-286.

Leinkumar, V. (2017). The relationship between customer satisfaction and customer trust on customer loyalty. International Journal of Academic Research in Business and Social Sciences, 7(4), 450-465.

Luximon, A., \& Chan, P. Y. (2017). Service quality expectation and cultural diversity in fast fashion retailing. Journal of Textile Engineering \& Fashion Technology, 1(3), 93-99.

Mistri, V. M., \& Bhatt, N. H. (2013). Retail store and service quality: A study on hypermarkets in Ahmedabad city. Pacific Business Review International, 6(4), 59-65.

Oliver, R.L. (1997). Satisfaction: A behavioral perspective on the consumer. McGraw-Hill, New York, NY.

Omar, M. S., Ariffin, H. F., \& Ahmad, R. (2016). Service quality, customers' satisfaction and the moderating effects of gender: A study of Arabic restaurants. Procedia-Social and Behavioral Sciences, 2(24), 384-392.

Parasuraman, A., Zeithaml, V. A., \& Berry, L.L. (1988). SERVQUAL: A multiple-item scale for measuring consumer perceptions of service quality. Journal of Retailing, 64(1), 12-40.

Priyo, J. S., Mohamad, B., \& Adetuji, R. R. (2019). An examination of the effects of service quality and customer satisfaction on customer loyalty in the hotel industry. International Journal of Supply Chain Management, 8(1), 653-663.

Rajeswari, S., Srinivasulu, Y., Thiyagarajan, S. (2017). Relationship among service quality, customer satisfaction and customer loyalty: With special reference to wireless telecom sector (DSL service). Global Business Review, 18(4), 1041-1058. doi: 10.1177/0972150917692405

Rouf, M. A., Kamal, M., \& Iqbal, M. M. (2018). Customers' perception of service quality of banking sectors in Bangladesh. International Journal of Law and Management, 60(4), 922-933.

Sekaran, U. \& Bougie, R. (2016). Research methods for business: A skill building approach (7th ed.). New Jersey: John Willey and Sons, Inc.

Selvabaskar, S., Shanmuga, Priya, G. (2015). A study on customer satisfaction across SERVQUAL dimensions for a fashion apparel retailer in Chennai. ERPA International Journal of Economic and Business review, 3(5), 112-115.

Shah, S. N. U., Jan, S., \& Baloch, Q. B. (2018). Role of service quality and customer satisfaction in firm's performance: Evidence from Pakistan hotel industry. Pakistan Journal of Commerce and Social Sciences, 12(1), 167-182.

Shahneaz M. A., \& Salma, U. (2013). Service quality in mega shops: A study of consumer satisfaction in apparel retailing. European Journal of Business and Management, 5(4), 248-254.

Singh, S. P., \& Aggarwal, B. (2017). Factors affecting customer satisfaction in textile industry: A study of Vardhman group. Biz and Bytes, 8(1), 158-187.

Singh, G., \& Kumar, M. (2016). Analyzing students' perception and attitude towards service quality delivery in higher educational institutions of Punjab. Global Business and Management Research: An International Journal, 8(1), 18-33.

Statista. (2018). Market demand of clothing in Malaysia from 2011 to 2018 (in billion U.S. dollars). Retrieved from https://www.statista.com/statistics/616418/malaysia-clothing-market-demand/ on June 16, 2018.

Streukens, S., \& Leroi-Werelds, S. (2016). Bootstrapping and PLS-SEM: A step-by-step guide to get more out of your bootstrap results. European Management Journal, 34(6), 618-632.

Suhrawardi, R. (Jan, 2019). The Big Issues Facing Fashion in 2019. Forbes. Retrieved from https://www.forbes.com/sites/rebeccasuhrawardi/2019/01/16/the-big-issues-facing-fashion-in2019/\#1015e4ee23a9

Tariq, B., \& Nik Mat, N. K. (2018). The determinants of customer loyalty in telecommunication industry of Pakistan. International Journal of Business Marketing and Management, 3(1), 36-43.

Tessera, F. A., Hussain, I. A., \& Ahmad, N. (2016). Service quality and hotel's customer satisfaction: An empirical evidence from Ethiopia. Electronic Journal of Business and Management, 1(1), 24-31.

Textiles Intelligence (2018). Prospects for the textile and clothing industry in Malaysia, 2018. 194. Retrieved from https://www.textilesintelligence.com/tistoi/?pageid=3\&repid=TISTOI\&issueid=194\&artid=2395

Whingan, S. O., \& Ogundare, E. A. (2018). Impact of service quality on customer satisfaction: the Malaysia bank customer experience. International Journal of Accounting \& Business Management, 6(2), 62-85. 